\title{
PRODUCT QUALITY OF DOMESTIC DUAL PURPOSE HYBRID CHICKENS UNDER CONDITIONS OF PRIVATE HOUSEHOLDS
}

\author{
Pankova Svetlana*, Katerynych Oleg \\ State Poultry Research Station of NAAS, Birky, Ukraine

\section{ЯКІСТЬ ПРОДУКЦІЇ ВІТЧИЗНЯНОГО ГІБРИДУ КУРЕЙ ПОДВІЙНОГО ПРИЗНАЧЕННЯ В УМОВАХ ПРИСАДИБНИХ ГОСПОДАРСТВ}

\section{Панькова Світлана, Катеринич Олег}

Received 21. 6. 2017

Revised 22. 6. 2017

Published 29. 11. 2017

Shows the results of the assessment of the quality of meat and eggs of a new Ukrainian hybrid of a dual purpose, obtained by crossing a native breed hens "Poltavska glinyasta" with cocks of factory line G2 white "Plymouth Rock" breed of domestic selection are presented. As a result, fattening cockerels during 12 weeks and their slaughter at the end of the experiment found a statistically significant advantage of hybrid young over the maternal form of live weight $(53.7 \%)$, eviscerated carcass weight $(60.7 \%)$, the output of an eviscerated carcass (3.1\%) and muscle tissue (72\%). For the chemical constituents hybrids meat is not inferior to the original form. Analysis of the physical and morphological indicators of eggs showed a significant advantage $(P>0.999)$ of the hybrid bird over the maternal line at the age of 30 weeks by the eggs weight ( 57.9 and $54.1 \mathrm{~g}$ ), yolk weight ( 16.2 and $14.3 \mathrm{~g}$ ) and the energy value of eggs ( 155.3 and $148.6 \mathrm{kcal})$. At 49 weeks of age egg quality parameters hybrid were at the level of parental forms egg weight $67.2 \mathrm{~g}$, the contents of the yolk in eggs $30.5 \%$, the ratio of albumin to the yolk -1.9 , indicating a high energy value of the product $-1628 \mathrm{kcal}$ per $100 \mathrm{~g}$ of egg mass. Thus, showed the double (combined) type of productivity of hybrid, which uses of is aimed at obtaining meat (with fattening cockerels) and eggs (while keeping hens) high quality.

Keywords: chickens; dual-purpose hybrid; meat qualities; chemical composition; quality of eggs; morphological indicators; energy value

\section{Вступ}

За останні п'ять десятиліть генетично детермінований антагонізм між темпом нарощування живої маси і інтенсивністю несучості призвів до диференціації спеціалізованих кросів для виробництва м'яса і яєць. 3 одного боку, це бройлери, які всього за 35 днів досягають живої ваги близько 2,1 кг при конверсії корму 1,6 кг корму на 1 кг приросту. 3 іншого, - несучки, які за 365 днів відкладають 295 яєць при конверсії корму 2,3 кг корму на 1 кг яєчної маси. Проте, на відміну від м'ясної птиці, де здійснюють відгодівлю і самців і самок, в яєчних кросах використання обох статей неможливе, що призводить до загибелі самців в добовому віці. Ця практика викликає все більшу стурбованість у суспільстві, щодо неї існують етичні та правові застереження (Bruijnis et al., 2015).

*Corresponding author: Svetlana Pankova, State Poultry Research Station of NAAS, Birky, Ukraine, svet_my@ukr.net 
Перспективним рішенням $є$ використання порід подвійного призначення (Preisinger et al., 2014). В цьому випадку обидві статі набувають економічної цінності, оскільки самці мають прийнятну швидкість росту і забійний вихід, а самки - показують високу несучість. Світові селекційні компанії пропонують птицю подвійного призначення, отриману при схрещуванні м'ясних і яєчних ліній з використанням зчепленого зі статтю гену карликовості, наприклад Lohmann Dual, Walesby Special, Novogen Dual та ін. Дослідження показали, що Lohmann Dual i Walesby Specials мають достатню м'ясну та яєчну продуктивність (Damme et al., 2015).

Останнім часом в Україні також зростає потреба споживачів, особливо фермерів, на птицю 3 комбінованою продуктивністю, яка вдало поєднує у собі достатню для домашнього господарстванесучістьімасуяєць,маючиприцьомугарнім'ясніякостіпривисокійжиттєздатності. Виходячи з цього, у Державній дослідній станції птахівництва НААН з використанням вітчизняного генофонду курей (самців заводської лінії Г2 м'ясо-яєчної породи Плімутрок білий і самок лінії 14 яєчно-м'ясної породи Полтавська глиниста) створений універсальний гібрид, який в умовах присадибних господарств $\epsilon$ досить ефективним для отримання як м'ясної, так іяєчної продуктивності (Панькова та ін., 2015; Катеринич і Панькова, 2016).

Метою роботи є оцінка якості продукції (м'яса і яєць) гібриду курей подвійного призначення, створеного для присадибного сектора з використанням аборигенної породи та птиці вітчизняної селекції різних напрямів продуктивності.

\section{Матеріали та методи}

Дослідження проведені в умовах експериментальної ферми "Збереження державного генофонду птиці" Державної дослідної станції птахівництва НААН України. Для вивчення м'ясних якостей гібридних півників у порівнянні до півників вихідних форм (Г2 та 14) від кожної групи було посаджено на вирощування по 60 голів у добовому віці. Курчат вирощували на підлозі, щільність посадки 5,0 - 5,5 гол./м², годівля вволю повнораціонним комбікормом для ремонтного молодняку (ОЕ - 290 кКал/100 г, СП - 20 \%). Термін відгодівлі становив 12 тижнів. Наприкінці досліду було забито по 5 голів від кожної групи для визначення маси і виходу патраної тушки, ножних і грудних м'язів та аналізу м'яса за такими показниками: вміст сирого жиру, сирого протеїну, вологи та золи. Забій та оцінку м'ясних якостей птиці було проведено згідно стандартних методик.

Для вивчення якості яєць на випробування було посаджено по 100 голів гібридних та чистопородних несучок. Дорослих курей утримували в двохярусних групових кліткових батареях за щільності посадки 9,5 - 9,8 гол./м², умови годівлі та утримання всіх груп відповідали нормативам. У віці курей 30 і 49 тижнів було вивчено наступні фізико-морфологічні показники яєць: маса й індекс форми яєць; маса шкарлупи, жовтка й білка; співвідношення маси білка й жовтка. Розрахунок енергетичної цінності яєць здійснювали за формулою, запропонованою А.Е. Остряковою та ін. (2003). Було досліджено по 30 яєць від кожної групи з використанням загальноприйнятих методик (Фисинин и Тишенков, 1998).

\section{Результати та їх обговорення}

Результати аналізу м'ясних якостей молодняку у віці 12 тижнів та хімічного складу м'яса наведено в таблиці 1. Встановлено вірогідне перевищення гібридних півників над материнською формою за живою масою (на 53,7 \%) та масою патраної тушки (на 60,7 \%). Вихід патраної тушки також був вищим у гібридів на 3,1%. При порівнянні цих показників у гібридів та батьківської форми відмічено протилежні результати, хоч і дещо меншою мірою, - перевага батьківської форми на 24 \% за живою масою, на 26,4 \% - за масою патраної тушки і всього на 2,1 \% - за виходом патраної тушки. 
Таблиця 1 Показники м'ясних якостей та якості м'яса гібридних та чистолінійних півників

Table 1

\begin{tabular}{|c|c|c|c|}
\hline \multirow[t]{2}{*}{ Показники } & \multicolumn{3}{|c|}{ Група птиці } \\
\hline & 「2 & 14 & $\Gamma 2 \times 14$ \\
\hline Передзабійна жива маса, г & $3340,7 \pm 169,9^{\mathrm{a} 1}$ & $1653,0 \pm 116,9$ & $2540,1 \pm 149,9^{62}$ \\
\hline Маса патраної тушки, г & $2304,7 \pm 133,5^{\mathrm{a} 1}$ & $1056,0 \pm 87,5$ & $1696,6 \pm 99,0^{62}$ \\
\hline Вихід патраної тушки, \% & 68,9 & 63,7 & 66,8 \\
\hline \multicolumn{4}{|l|}{ Маса м'язів, г: } \\
\hline грудних & $405,7 \pm 29,5^{\mathrm{a} 1}$ & $158,1 \pm 19,5$ & $286,5 \pm 26,2^{\mathrm{a} 2}$ \\
\hline стегна & $264,2 \pm 22,0^{\mathrm{a} 1}$ & $112,3 \pm 12,8$ & $183,7 \pm 8,9^{62}$ \\
\hline гомілки & $219,0 \pm 13,8^{\mathrm{a} 1}$ & $99,9 \pm 10,8$ & $168,1 \pm 13,0^{62}$ \\
\hline \multicolumn{4}{|c|}{ Відносна маса м'язів (до патраної тушки), \%: } \\
\hline грудних & 17,6 & 15,0 & 16,9 \\
\hline стегна & 11,5 & 10,6 & 10,8 \\
\hline гомілки & 9,5 & 9,5 & 9,9 \\
\hline \multicolumn{4}{|c|}{ Хімічний склад грудних м'язів, \%: } \\
\hline волога & 71,85 & 74,65 & 74,52 \\
\hline сирий протеїн & 18,20 & 19,72 & 19,39 \\
\hline сирий жир & 4,82 & 0,14 & 0,61 \\
\hline зола & 5,13 & 5,49 & 5,48 \\
\hline $\begin{array}{l}\text { Енергетична цінність } 100 \text { г } \\
\text { грудних м'язів, кКал }\end{array}$ & 119,4 & 82,2 & 85,2 \\
\hline \multicolumn{4}{|c|}{ Хімічний склад ножних м'язів, \%: } \\
\hline волога & 71,17 & 72,14 & 74,09 \\
\hline сирий протеїн & 17,59 & 17,05 & 16,49 \\
\hline сирий жир & 8,39 & 7,77 & 5,36 \\
\hline зола & 2,85 & 3,04 & 4,06 \\
\hline $\begin{array}{l}\text { Енергетична цінність } \\
100 \text { г ножних м'язів, кКал }\end{array}$ & 150,1 & 142,2 & 117,5 \\
\hline
\end{tabular}

a1 - вірогідно при порівнянні гібрида (Г2 ×14) та батьківської форми (Г2): ${ }^{\text {a1 }}-P>0,95 ;{ }^{\text {a2 }},{ }^{62}$ - вірогідно при порівнянні гібрида (Г2 × 14) та материнської форми (14): ${ }^{22}-P>0,95,{ }^{62}-P>0,99$

В 49-тижневому віці гібридна птиця переважала обидві батьківські форми за масою яйця - на 0,4 - 5,6 г, що, очевидно, обумовлено проявом у них ефекту гетерозису. Ця перевага була вірогідною порівняно до материнської лінії в обидва вікові періоди $(P>0,999)$. За індексом форми яєць не спостерігалося істотної різниці між вихідними формами й гібридом, а також відзначено, що цей показник не залежав від віку птиці й перебував на рівні 72,9 - 73,9%.

Відмічено також незначні міжгрупові відмінності за масою білка й жовтка у віці 30 тижнів. У гібридної птиці вміст жовтка в яйцях був максимальним - 28,1 \%, що на 0,6 - 1,7 \% вище, ніж 
у вихідних форм. Вміст білка в цьому віці найвищим був у яйцях курей материнської форми - на 1,9 - 2,0 \%, вище, ніж в інших групах. До 49-тижневого віку птиця всіх груп практично зрівнялася за вивченими характеристиками складових частин яйця.

За енергетичною цінністю яєць (у розрахунку на 100 г яєчної маси) всі групи птиці перебували майже на одному рівні. При цьому варто відзначити, що яйця, отримані від курей у віці 49 тижнів, мали енергетичну цінність вище на 7,5 - 12,7 кКал, ніж від більш молодої птиці, за рахунок збільшення в них частки жовтка.

Таким чином, яйця дорослих гібридних курей за фізико-морфологічними параметрами якості не поступаються вихідним формам і навіть переважають їх - за масою на 0,6 - 9,2%, вмістом жовтка на 0,1 - 0,6 \%, за енергетичною цінністю на 0,9 - 4,5\%.

\section{Висновки}

Дослідженнями доведено подвійний тип продуктивності нового українського гібриду курей, використання якого спрямоване на отримання м'яса та яєць високої якості. Оцінка забійних якостей півників в результаті відгодівлі протягом 12 тижнів свідчить про істотну перевагу гібридів над материнською формою, яка має яєчно-м'ясний напрям продуктивності: маса патраної тушки більша - на 60,7 \%, вихід патраної тушки - на 3,1 \%, м'язової тканини - на $2,5 \%$. За хімічними складовими м'ясо гібрида не поступалося вихідним формам. Аналіз фізико-морфологічних показників яєць показав їх високу масу у гібридних несучок - 67,2 г, вміст жовтка в яйцях - 30,5 \%, енергетичну цінність 100 г яйцемаси - 162,8 кКал, що відповідає рівню батьківської форми. Ці результати свідчать про високу якість продукції птиці вітчизняної селекції - яєчно-м'ясної аборигенної породи Полтавська глиняста, м'ясо-яєчної породи Плімутрок білий і нового гібриду, отриманого при їхньому схрещуванні.

\section{Література}

Bruijnis, M. R. N., Blok, V., Stassen, E. N., Gremmen, H. G. J. 2015. Moral “Lock-In” in Responsible Innovation: The Ethical and Social Aspects of Killing Day-Old Chicks and Its Alternatives. J. Agric. Environ. Ethics, vol. 28, no. 5, p. 939-960.

Damme, K., Urselmans, S., Schmidt, E. 2015. Economics of Dual-Purpose Breeds. Lohmann Information, vol. 50, no. 2, p. 4-9.

Preisinger, R., Icken, W., Schmutz, M. 2014. Breeding dual-purpose chicken opposed to specialised hybrids. Proc. XIV European Poultry Conference, Stavanger, Norway, p. 468.

Катеринич, О. Панькова, С. 2016. Новое гибридное сочетание птицы. Животноводство России, № 10, p. 11-12.

Острякова, А.Е., Подстрешный, А.П., Бреславец, В.А. 2003. Физико-морфологические показатели качества яиц различных линий и гибридов кур. Птахівництво: міжвід. темат. наук. зб., № 53, p. 93-106.

Панькова, С.М., Катеринич, О.О., Захарченко, О.П., Фесенко Н.А. 2015. Новий вітчизняний м'ясо-яєчний гібрид для присадибного та органічного виробництва (економічна ефективність вирощування півників). Сучасне птахівничтво, № 5, р. 21-24.

Фисинин, В.И., Тишенков, А.Н. 1998. Оченка качества кормов, органов, тканей, яиц и мяса птицы. Сергиев Посад: ГНУ ВНИТИП. 113 р. 